УДК $336.71 ; 338.124 .4$

\title{
СОВРЕМЕННОЕ СОСТОЯНИЕ БАНКОВСКОЙ СИСТЕМЫ КАЗАХСТАНА В УСЛОВИЯХ КРИЗИСА
}

\section{ЖАГЫПАРОВА Аида Орынтаевна}

кандидат экономических наук, ассочированный профессор кафедры финансов Евразийского национального университета имени Л. Н. Гумилева, Казахстан e-mail:Zhagyparova_Aida@mail.ru

\section{СЕМБИЕВА Ляззат Мыктыбековна}

доктор экономических наук, профессор кафедры финансов Евразийского начионального университета имени Л. Н. Гумилева, Казахстан

ORCID ID: https://orcid.org/0000-0001-7926-0443

e-mail:sembiyeva@mail.ru

\section{САМАРХАН Гүлия Айдосқызы}

студентка,

Евразийский начиональный университет имени

Л.Н. Гумилева, Казахстан

Аннотация. $B$ статье исследован практический опыт становления и реформирования банковской системы Республики Казахстан с 1987 г., проанализированы качественные показатели деятельности коммерческих банков, предложены меры с помощьью которых можно улучшить финансовое развитие банковской системы Казахстана в условиях кризиса.

Ключевые слова: банковская система, финансовая устойчивость, кризис, антикризисные меры, Начиональный банк Республики Казахстан.

Постановка проблемы. Финансовый кризис вызвал широкий резонанс в мире, показал уязвимость банковских систем большинства государств. Банковские кризисы отражают сложный процесс приспособления банковских систем к новым макроэкономи-
Анотація. У статті досліджено практичний досвід становлення та реформування банківської системи Республіки Казахстан 3 1987 р., проаналізовані якісні показники діяльності комериійних банків, запропоновані заходи за допомогою яких можна поліпшити фінансовий розвиток банківської системи Казахстану в умовах кризи.

Ключові слова: банківська система, фiнансова стійкість, криза, антикризові заходи, Національний банк Республіки Казахстан.

ческим условиям.

В условиях мирового кризиса отношения руководителей коммерческих банков Республики Казахстан (далее - РК) подверглись значительным изменениям. Присутствует тенденция ужесточения требования к за- 
емщикам, практически выдача кредитов уменьшилась, постоянно проводятся анализ и оценка рисков. Одним из первоисточников банковского кризиса в Казахстане явилось бесконтрольное внешнее заимствование. Республика столкнулась с негативными последствиями мирового экономического кризиса, государство оказало огромную помощь финансовой системе, при этом заботясь о реальной экономике и благосостоянии граждан.

В период кризисных явлений государство заинтересовано в поддержке банков в целях обеспечения устойчивости всей финансовой системы и экономики. В связи с этим, Президентом РК поручено принять комплекс мер по оздоровлению банковского сектора. Не своевременное принятие данных мер может снизить доверие к банкам, как экономическим посредникам, привести к нестабильности экономики.

Анализ последних исследований и публикаций. Теоретической основой исследования послужили работы по теории банковского дела С.Б.Макыша, Г.С. Сейткасимова, О.И. Лаврушина, И.Д. Мамоновой, Gerald Jr., Daniela, Rym Ayadi, Paul Newson, Mishra Diveshи др. В ходе исследования изучены общая и специальная литература, разработки ведущих организаций по системе оценки кредитных рисков теории банковского дела, материалы научных конференций и семинаров, законодательные и другие нормативные акты, соответствующие методические и проектные материалы, a также рекомендации зарубежных исследователей по вопросам формирования и оптимизации деятельности банков.

Целью статьи является обоснова- ние мер по повышению финансовой устойчивости банковской системы РК в условиях финансового кризиса.

Изложение основного материала исследования. Современная экономика представляет собой очень сложную систему, каждая часть которой тесно связана с другими и играет важную роль. Но, одну из важнейших ролей играет банковская система, обеспечивающая на современном этапе развития экономических взаимоотношений нормальное функционирование всей экономики в целом.

Сейчас невозможно представить гармонично развитое государство без разветвленной сети банков. И действительно, банки играют в современной экономике роль многочисленных сердец, с помощью которых возможно развитие и становление экономикополитической мощи государства. На сегодняшний день, банки являются экономическим инструментом в руках правительства [1]. Самыми важными задачами банков являются: обеспечение бесперебойного денежного оборота и оборота капитала, предоставление широкого круга возможностей вложения денежных средств с целью накопления сбережений народного хозяйства.

Современная банковская система Казахстана сложилась в результате различных преобразований, проведенных в рамках банковской реформы, осуществляемой с 1987 года. Ее формирование делится на три этапа:

На первом этапе (1988-1991 гг.) в условиях существования СССР была проведена реорганизация государственных отраслевых специализированных банков путем передачи части функций центра в республиканские подразделения соответствующих бан- 
ков, созданы первые коммерческие банки и сделаны начальные шаги по передаче Госбанку отдельных функций центрального банка.

Второй этап (1992-1993 гг.) характеризуется постепенным переходом Национального банка (далее - НБ) РК к выполнению ряда функций центрального банка в рамках существования рублевой зоны, экстенсивным формированием и развитием коммерческих банков, началом формирования национальной банковской нормативно-правовой базы.

На третьем этапе (с ноября 1993 г.) в связи с введением национальной валюты на НБ РК была возложена полная ответственность за функционирование денежно-кредитной сферы. Вводились классические принципы его взаимоотношений с бюджетом и банками, укреплялась система регулирования деятельности банков [2]. Организационно-правовое оформление двухуровневой банковской системы произошло с принятием Закона Казахской ССР от 7 декабря 1990 г. «О банках и банковской деятельности в Казахской ССР». Дальнейшее совершенствование и реорганизация банковской системы происходило с принятием Закона РК от 13 апреля 1993 г. «О Национальном банке Республики Казахстан», Закона РК от 14 апреля 1993 г. «О банках в Республике Казахстан», «Постановления Президента РК от 15 февраля 1995 г. № 2044 «Об утверждении Программы реформирования банковской системы в Казахстане на 1995 г.», Указа Президента РК, имеющего силу закона, от 31 сентября 1995 г. «О банках и банковской деятельности в Республике Казахстан».

На четвертом этапе (2004г.) произошли кардинальные изменения в кредитной системе страны. НБ был реорганизован путем выделения из него государственного учреждения «Агентство Республики Казахстан по регулированию и надзору финансового рынка и финансовых организаций» (Указ Президента РК от 31 декабря 2003 г.) [2, 172], после функции и полномочия Агентства были переданы новообразованному Комитету по контролю и надзору финансового рынка и финансовых организаций НБ РК (Указ Президента РК от 12 апреля 2011 года № 25), а с 1 января 2020 года функционирует новый государственный орган РК - Агентство Республики Казахстан по регулированию и развитию финансового рынка (Указ Президента РК от 11 ноября 2019 года №203 «О дальнейшем совершенствовании системы государственного управления Республики Казахстан»).

Агентство является государственным органом, обеспечивающим надлежащий уровень защиты прав и законных интересов потребителей финансовых услуг, содействующим обеспечению стабильности финансовой системы и развитию финансового рынка, осуществляющим государственное регулирование, контроль и надзор финансового рынка и финансовых организаций, а также иных лиц в пределах компетенции [4].

В настоящее время Республика Казахстан имеет двухуровневую банковскую систему. На первом уровне находится НБ РК. На втором - все остальные банки (рис.1).

НБ РК является государственным органом, обеспечивающим разработку и проведение денежно-кредитной политики государства, функционирование платежных систем, осуществляющим валютное регулирование и ва- 
лютный контроль, содействующим обеспечению стабильности финансовой системы и проводящим государственную статистику, а также осуществляющим в пределах своей ком- петенции государственное регулирование, контроль и надзор за финансовым рынком, финансовыми организациями и иными лицами и в области финансового законодательства РК [5].

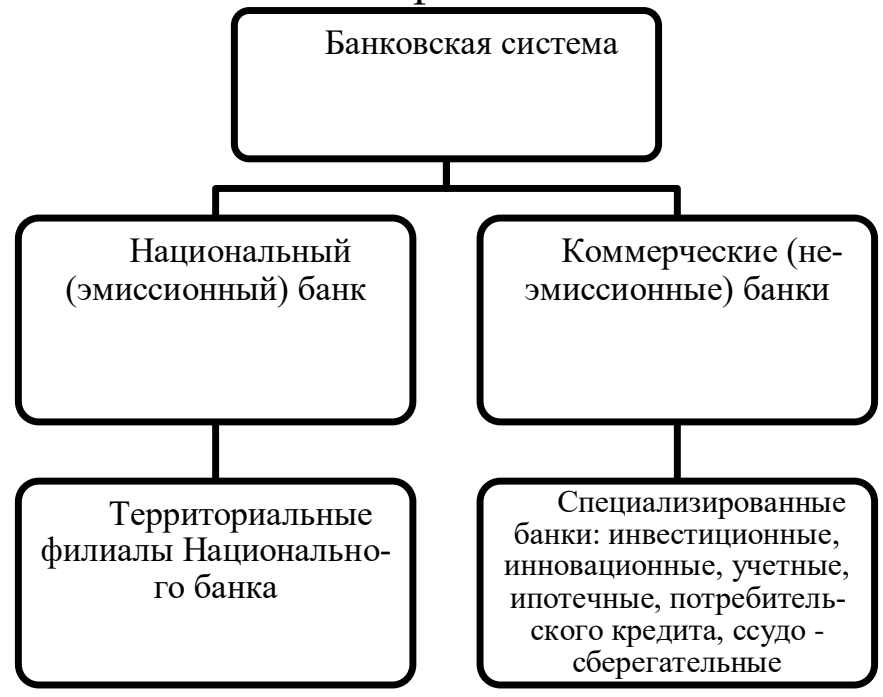

Рис. 1. Банковская система Казахстана

Источник: составлено автором на основе [3]

Законом «О банках и банковской деятельности» определено, что банки второго уровня создаются в форме акционерных обществ без права выпуска акций на предъявителя. Банки могут образовываться на основе любой формы собственности, за исключением государственных банков, которые создаются только на основе государственной собственности. Учредителями и акционерами банков могут быть юридические и физические лицанерезиденты Казахстана с учетом особенностей создания дочерних банков банками-нерезидентами РК, предусмотренные законом. Банкам второго уровня разрешается привлечение денежных средств от юридических и физических лиц, открытие и введение корреспондентских счетов банков и небанковских финансовых учреждений, а также металлических счетов банков; осуществление кассовых, переводных, учетных, ссудных, трасто- вых, клиринговых, сейфовых, ломбардных операций; финансирование капитальных вложений; также разрешено проведение операций с иностранной валютой [7]. По состоянию на 1 марта 2021 года в РК функционируют 25 банков, из них 15 банков с иностранным участием, в том числе 12 дочерних банков второго уровня, 1 банк со 100\% государственным участием (рис. 2).

Тенденция сокращения количества банков в условиях роста неопределенности была обусловлена рядом причин. К их числу можно отнести: отзывы лицензий, слияния с другими банками, преобразования в филиал, добровольная ликвидация и другие причины.

Банковский сектор Казахстана продолжает оставаться основным каналом перемещения денежных средств из финансового сектора в реальный сектор экономики. Его состояние в насто- 
ящий момент определяет влияние трех системных факторов - это снижение доступа к дешевым внешним ресурсам, нерешенные структурные про- блемы в экономике, колебания валютного курса.

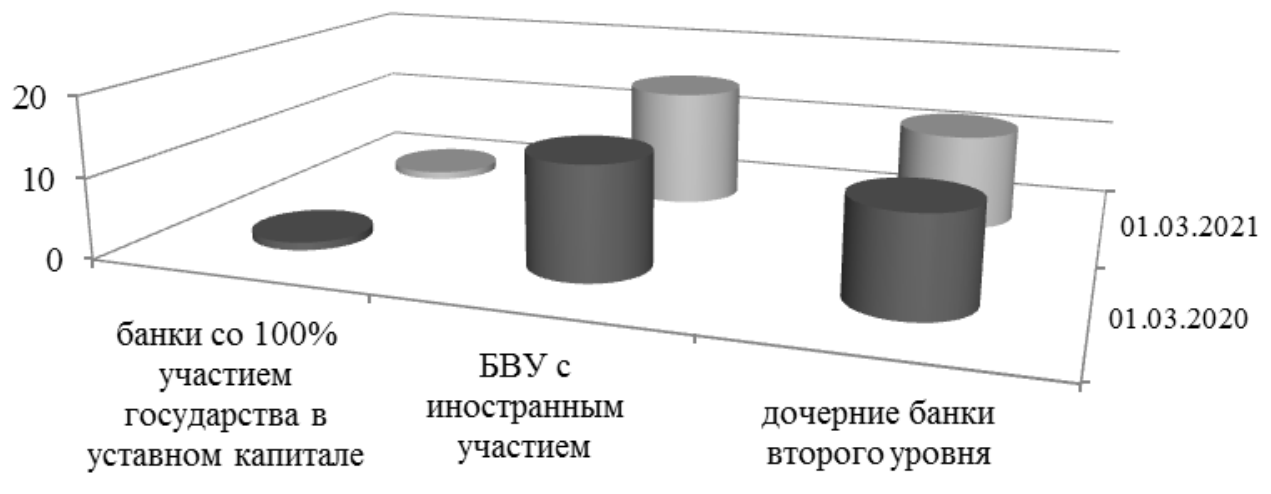

Рис. 2. Структура банковского сектора РК

Источник: составлено автором на основе [11], [12]

Из табл. 1 можно понять, что банковской сектор имеет значимую роль в экономике Казахстана. Большую часть охватывает отношение активов к ВВП
- 41,6 \%, а коэффициент размещения части средств во внутренние активы на 01.03.2021 г. составляет 1,053.

Таблица 1

Роль банковского сектора в экономике РК

\begin{tabular}{|l|c|c|}
\hline \multicolumn{1}{|c|}{ Наименование показателя } & 01.03 .20 & 01.03 .20 \\
\hline ВВП, млрд. тг & 20 & 21 \\
\hline Отношение активов к ВВП, \% & 69679,6 & 74961,6 \\
\hline Отношение ссудного портфеля к ВВП, \% & $38,4 \%$ & $41,6 \%$ \\
\hline Отношение вкладов клиентов к ВВП, \% & $20,9 \%$ & $20,5 \%$ \\
\hline Коэффициент размещения части средств во внутренние активы & $25,6 \%$ & $29,5 \%$ \\
\hline
\end{tabular}

Источник: составлено автором на основе [11], [12]

Устойчивая банковская система крайне важна для безопасного функционирования государства, ее успешное развитие необходимо для экономики, так как она обеспечивает кредитно-финансовое обслуживание всего хозяйственного оборота страны [8]. В условиях экономической нестабильности происходит эскалация негативных факторов в финансово-кредитной сфере. Это требует от современных коммерческих банков адекватной системы управления финансовой устой- чивостью, в основе которой - диагностика финансового состояния банка. Аспекты анализа и оценки финансового состояния банка приобретают самостоятельное теоретическое и прикладное значение. Всесторонний анализ финансового состояния банка повышает надежность как отдельного банка, так и всей банковской системы в целом.

Финансовая устойчивость коммерческого банка может рассматриваться как комплексная характеристика, от- 
ражающая состояние его финансовых ресурсов, которые обеспечивают все аспекты деятельности банка и позволяют сохранять платежеспособность, ликвидность, прибыльность [9]. Обеспечение финансовой устойчивости является основополагающей целью деятельности любого коммерческого банка. Следовательно, управленческая система банка должна быть настроена таким образом, чтобы движение всех имеющихся ресурсов (финансовых, информационных, человеческих, временных, технических) было направлено на достижение вышеуказанной цели. Финансовая устойчивость банка определяется результатами оценки его финансового состояния на определенный момент времени. В экономической литературе выделяют 4 типа финансовой устойчивости (табл. 2).

Таблица 2

Типы финансовой устойчивости

\begin{tabular}{|c|l|l|}
\hline$№$ & Наименование & Сохранение финансовой устойчивости \\
\hline 1. & текущая & на данный момент времени \\
\hline 2. & краткосрочная & на срок до 90 дней \\
\hline 3. & среднесрочная & на срок до 180 дней \\
\hline 4. & долгосрочная & на срок свыше 180 дней \\
\hline
\end{tabular}

Источник: составлено автором на основе [10]

Для лучшего понимания процессов, происходящих внутри банка, а также процессов взаимодействия банка с окружающей средой целесообразно использовать системный подход как один из наиболее современных и распространенных методов исследования различных объектов. Рассматривая современный коммерческий банк как открытую социально-экономическую систему, можно утверждать, что на финансовую устойчивость оказывают влияние две группы факторов: внешние (включают факторы макросреды, а также факторы инфраструктуры региона, в котором функционирует банк) и внутренние (происходящие внутри банка взаимодействия составляющих его элементов (подразделений или конкретных сотрудников) для достижения поставленных целей).

Основными источниками проявления кризисных явлений в банковском секторе РК являются кредитная экспансия, внешний долг банковской системы, слабость ресурсной базы бан- ков Казахстана, высокая концентрация банковской системы и кредитный либерализм.

Практика показывает, что кризисы неодинаковы не только по своим причинам и последствиям, но и по своей сути. Существуют специфические особенности в типологии банковских кризисов. Необходимость в разветвленной классификации кризисов связана с дифференциацией средств и способов управления ими. Многообразие кризисных ситуаций обусловлено открытостью банковской отрасли как системы, взаимодействием с внешней и внутренней средой. Кризис в банковской сфере можно охарактеризовать по классификационным признакам, учитывающим индивидуальные особенности протекания кризиса в банках. Мировой кризис привнес достаточно много новых факторов, влияющих на банковский сектор РК, которые складываются в новые доминанты развития финансовой системы Казахстана. Если рассматривать фи- 
нансовые аспекты среди тенденций, преобладающих в последнее время, то можно выделить следующие: резкое сокращение темпов роста банковской системы, существенное ухудшение качества активов, снижение доходности казахстанских банков.

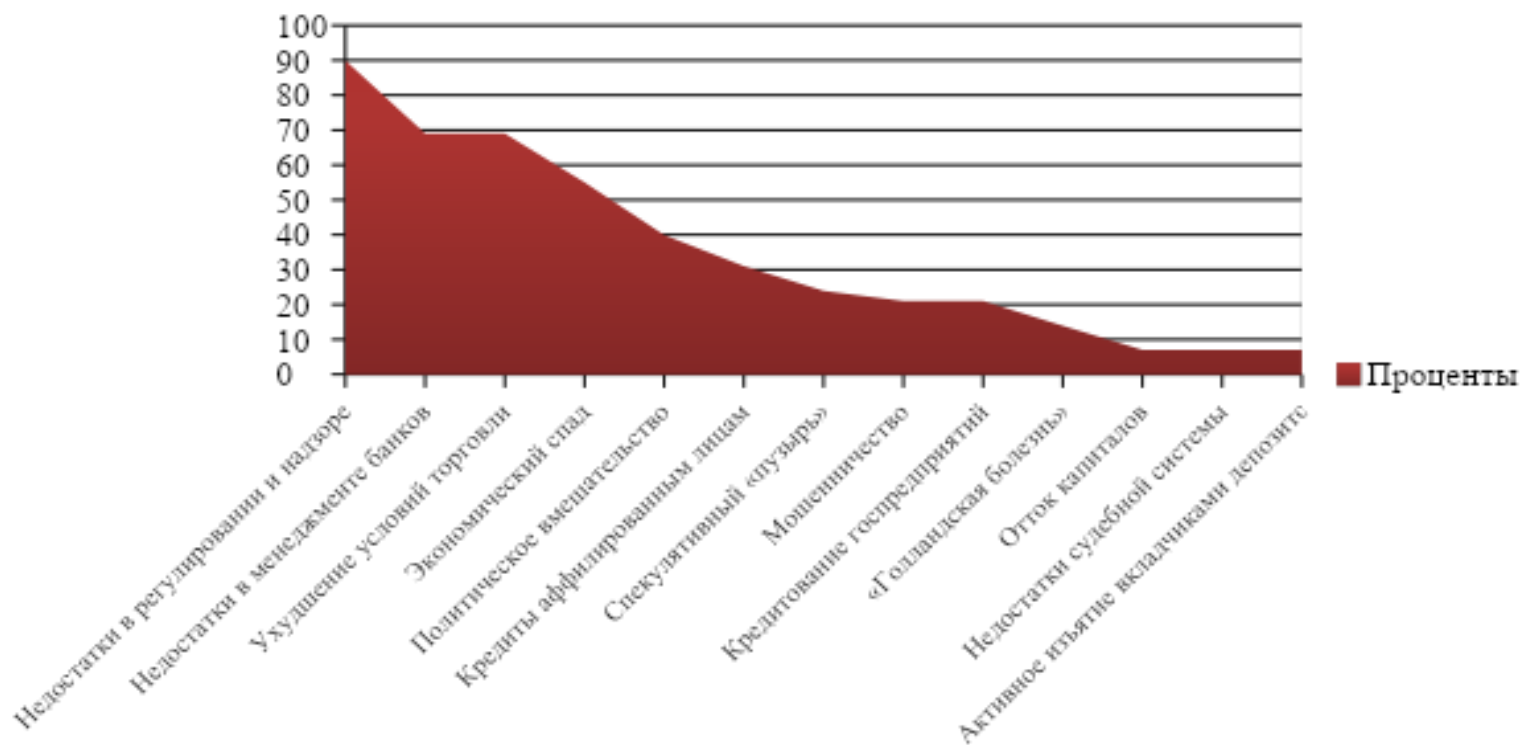

Рис. 3. Степень влияния различных факторов на развитие кризисных явлений в банковском секторе

Источник: составлено автором на основе [15]

Анализ и оценка финансового состояния коммерческого банка являются важными элементами процесса управления. С помощью анализа, как функции управления, осуществляется внутреннее регулирование деятельности банка. Дальнейшее изложение материала будет основываться на понимании того, что субъектом анализа является управленческий коллектив коммерческого банка, на который возложены соответствующие аналитикоконтрольные функции. Проанализируем основные показатели функционирования банковского сектора РК и антикризисные меры НБ РК.

Активы банков второго уровня РК по состоянию на 01.03.2021 г. составили 31995,4 млрд. тг (на 01.01.2021 г. - 31 171,7 млрд. тг), увеличение с начала 2021 г. - 2,6\%. В структуре активов наибольшую долю $(45,3 \%)$ занимает ссудный портфель (основной долг) в сумме 15373,2 млрд. тг (уменьшение с 01.01.2021 г. на $2,7 \%$ с $15 \quad 792,1$ млрд. тенге) (табл. 3).

Вклады клиентов занимают значительную часть пассивов, в 2020 г. 17813,8 млрд. тг или 66,6\%, в 2021 г. 22106,4 млрд. тг или 69,1\%. Год за годом вклады клиентов увеличиваются и сохраняет свою позицию. Вклады клиентов по состоянию на 01.03.2021 г. составляют 22106,4 млрд. тг или $79,2 \%$ от совокупных обязательств, прирост с 01.03 .2020 г. составил 4292,6 млрд. тг или 24\%, в частности, прирост вкладов юридических лиц составил 2479,1 млрд. тг, вкладов физических лиц $-16 \%$ (рис. 4).

Регулятивный капитал за год показал позитивную динамику и на 01.03.2021 г. составил 4942,8 млрд. тг, коэффициенты достаточности капита- 
ла к1 - 21,8\%, к1-2 -21,8\%, к2 - 27,4\% (табл. 4).

Таблица 3

Структура совокупных активов банковского сектора РК

\begin{tabular}{|l|c|c|c|c|}
\hline \multirow{2}{*}{ Наименование показателя } & \multicolumn{2}{|c|}{01.03 .2020} & \multicolumn{2}{c|}{01.03 .2021} \\
\cline { 2 - 5 } & $\begin{array}{c}\text { млрд. } \\
\text { тГ }\end{array}$ & $\begin{array}{l}\text { в \% к } \\
\text { итогу }\end{array}$ & млрд. тг & $\begin{array}{c}\text { в \% к } \\
\text { итогу }\end{array}$ \\
\hline $\begin{array}{l}\text { Наличные деньги, аффинированные драгметаллы и } \\
\text { корреспондентские счета }\end{array}$ & 3374,9 & 11,7 & 3100,2 & 9,1 \\
\hline Вклады, размещенных в других банках & 1874,4 & 6,5 & 4826,6 & 14,2 \\
\hline Ценные бумаги & 6423,4 & 22,3 & 7855,3 & 23,1 \\
\hline Банковские займы и операции «обратное РЕПО» & 14537,6 & 50,4 & 15373,2 & 45,3 \\
\hline Инвестиции в капитал & 479,3 & 1,7 & 584,1 & 1,7 \\
\hline Прочие активы & 21555,3 & 7,5 & 2234,2 & 6,6 \\
\hline Всего активы (без учета резервов (провизий)) & 28844,9 & 100 & 33973,5 & 100 \\
\hline $\begin{array}{l}\text { Резервы (провизии) в соответствии с требованиями } \\
\text { международных стандартов финансовой отчетности, } \\
\text { в том числе: }\end{array}$ & $-2114,5$ & $-7,3$ & $-1978,1$ & $-5,8$ \\
\hline $\begin{array}{l}\text { Резервы (провизии) по корреспондентским счетам и } \\
\text { вкладам в других банках }\end{array}$ & $-5,1$ & 0,0 & $-5,0$ & 0,0 \\
\hline Резервы (провизии) по ценным бумагам & $-34,9$ & $-0,1$ & $-39,8$ & $-0,1$ \\
\hline $\begin{array}{l}\text { Резервы (провизии) по банковским займам и опера- } \\
\text { циям «Обратное РЕПО» }\end{array}$ & $-1949,2$ & $-6,8$ & $-1795,4$ & $-5,3$ \\
\hline $\begin{array}{l}\text { Резервы (провизии) на покрытие убытков по инвести- } \\
\text { циям в дочерние и ассоциированные организации }\end{array}$ & $-47,3$ & $-0,2$ & $-0,1$ & 0,0 \\
\hline $\begin{array}{l}\text { Резервы (провизии) по прочей банковской деятельно- } \\
\text { сти и по дебиторской задолженности }\end{array}$ & $-77,9$ & $-0,3$ & $-137,8$ & $-0,4$ \\
\hline Всего активы & 26730,5 & & 31995,4 & \\
\hline
\end{tabular}

Источник: составлено автором на основе [11], [12]

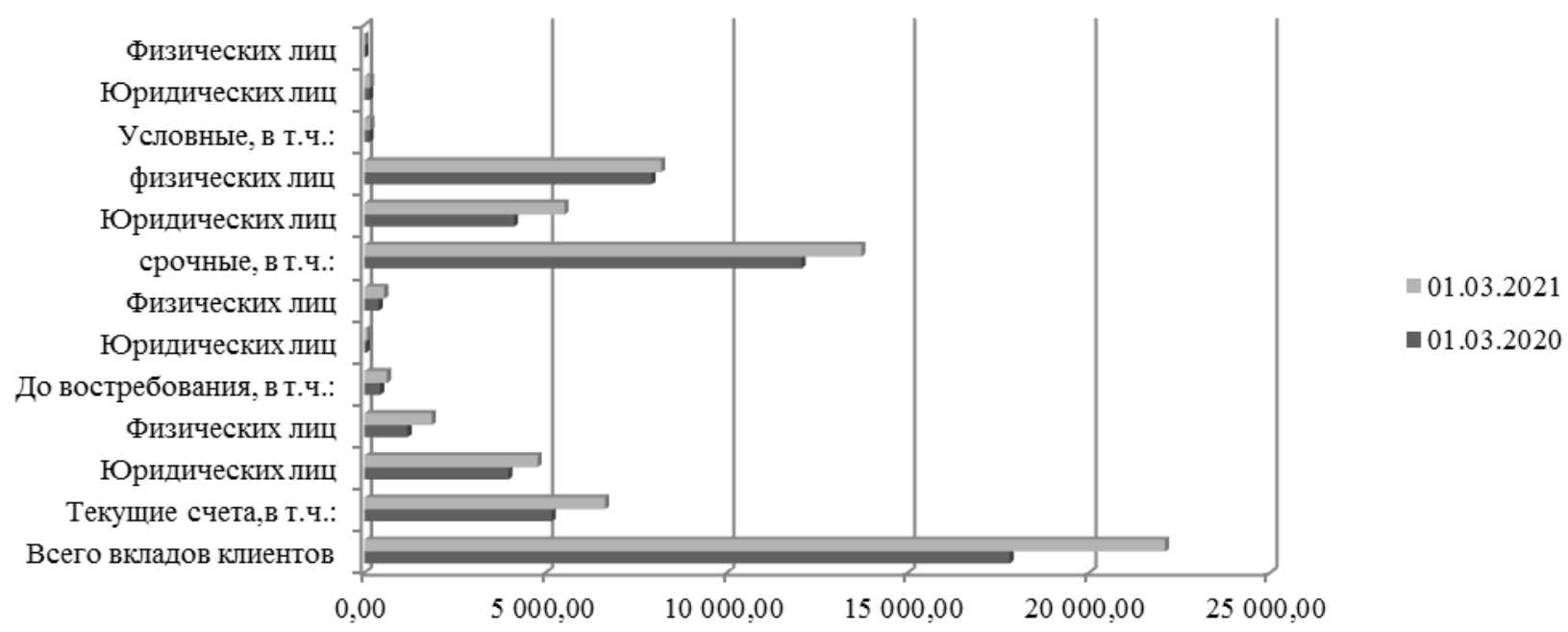

Рис. 4. Динамика вкладов банковского сектора РК

Источник: составлено автором на основе [11], [12]

Позитивную динамику за период исследования продемонстрировали также коэффициенты ликвидности $\mathrm{k} 4$, k4-1, k4-2, k4-3 (рис. 5). Высоколик- видные активы (среднемесячное значение) составили 9 326,3 млрд. тг или $34,9 \%$ от активов (на начало 2020 г. - 
9 174,6 млрд. тг), увеличение с начала 2020 г. $-1,7 \%$.

Таблица 4

Достаточность собственного капитала банковского сектора РК

\begin{tabular}{|l|c|c|c|c|}
\hline \multirow{2}{*}{ Наименование } & \multicolumn{2}{|c|}{01.03 .2020} & \multicolumn{2}{c|}{01.03 .2021} \\
\cline { 2 - 5 } & млрд. тг & $\%$ & млрд. тг & $\%$ \\
\hline Капитал первого уровня, в том числе: & 3694.4 & 79.7 & 3931.7 & 79.5 \\
\hline Основной капитал & 3689.6 & 79.6 & 3927.1 & 79.5 \\
\hline Добавочный капитал & 4.6 & 0.1 & 4.6 & 0.1 \\
\hline Капитал второго уровня & 938.5 & 20.3 & 1011.1 & 20.5 \\
\hline Корректировка собственного капитала & 162.8 & 3.51 & 58.3 & 1.18 \\
\hline Всего расчетный собственный капитал & 4633.0 & 100 & 4942.8 & 100 \\
\hline $\begin{array}{l}\text { Коэффициент достаточности собственного } \\
\text { капитала k1 }\end{array}$ & - & 19.8 & - & 21.8 \\
\hline $\begin{array}{l}\text { Коэффициент достаточности собственного } \\
\text { капитала к1-2 }\end{array}$ & - & 19.8 & - & 21.8 \\
\hline $\begin{array}{l}\text { Коэффициент достаточности собственного } \\
\text { капитала к2 }\end{array}$ & - & 24.8 & - & 27.4 \\
\hline
\end{tabular}

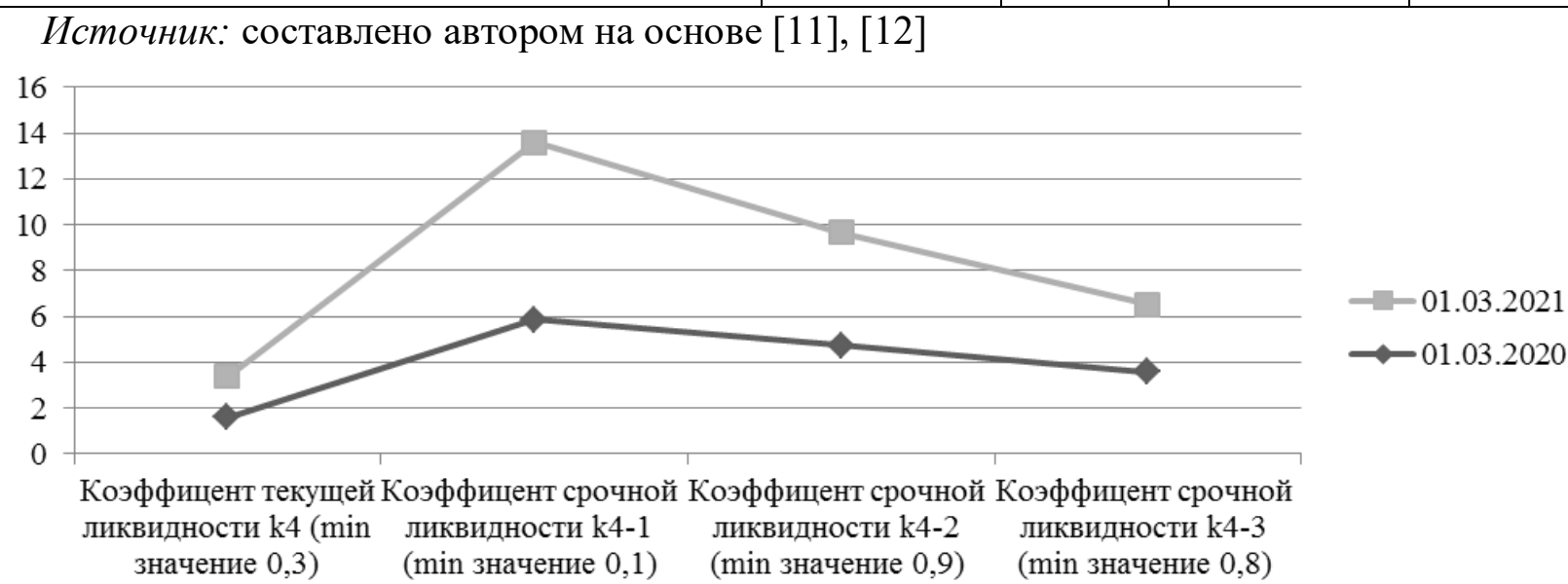

Рис. 5. Динамика ликвидности банковского сектора РК

Источник: составлено автором на основе [11], [12]

При этом, доходность банковского сектора остается стабильной (рис. 6).
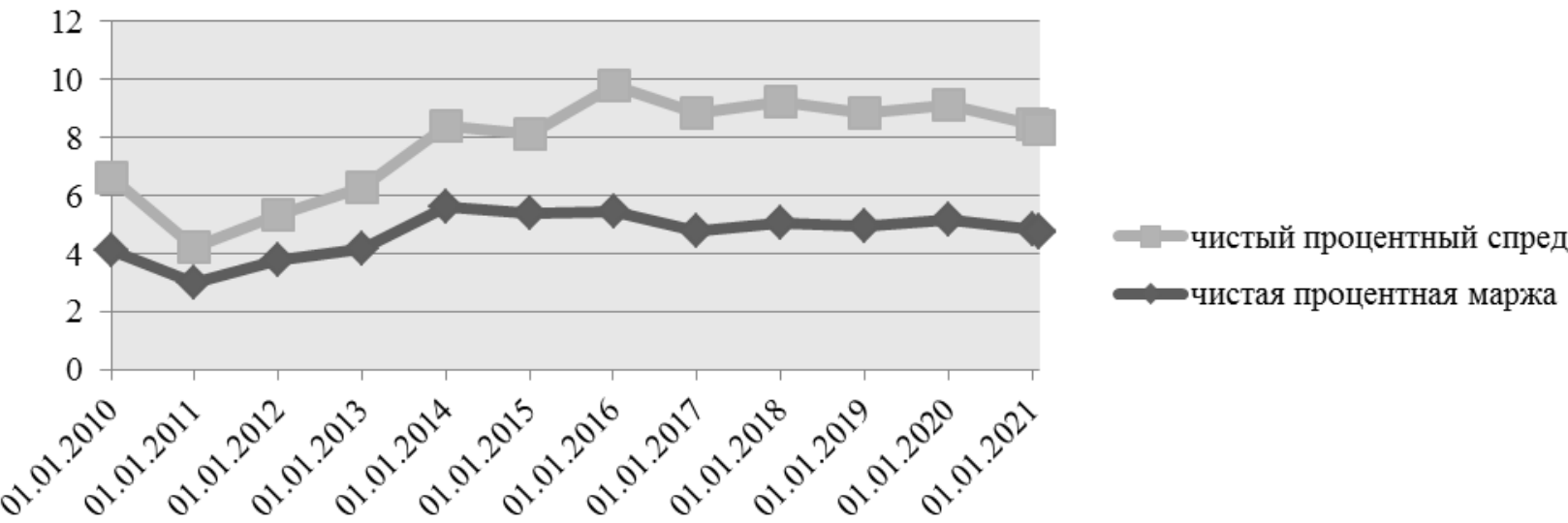

Рис. 6. Доходность банковского сектора РК

Источник: составлено автором на основе [11], [12] 
Анализ концентрации банковского сектора РК показал, что по состоянию на 01.03.2021 г. доля 5 крупнейших банков в совокупных активах банковского сектора снизилась с $64,0 \%$ до
63,9\%, в совокупных вкладах клиентов - увеличилась до $67,1 \%$, в совокупном ссудном портфеле - увеличилась до 66,4\% (табл. 5).

Таблица 5

Концентрация банковского сектора РК

\begin{tabular}{|c|c|c|}
\hline Наименование показателя & $\begin{array}{l}01.01 .20 \\
21\end{array}$ & $\begin{array}{l}01.03 .2 \\
021\end{array}$ \\
\hline $\begin{array}{l}\text { Доля } 5 \text { крупнейших банков в совокупных активах банковского } \\
\text { сектора РК }\end{array}$ & $64,0 \%$ & $63,9 \%$ \\
\hline $\begin{array}{l}\text { Доля } 5 \text { крупнейших банков в совокупным ссудном портфеле } \\
\text { банковского сектора РК }\end{array}$ & $64,5 \%$ & $66,4 \%$ \\
\hline $\begin{array}{l}\text { Доля } 5 \text { крупнейших банков в совокупных вкладах клиентов } \\
\text { банковского сектора РК }\end{array}$ & $66,5 \%$ & $67,1 \%$ \\
\hline
\end{tabular}

Источник: составлено автором на основе [11], [12]

Оценка антикризисных мер НБ РК свидетельствует о том, что на фоне негативного влияния пандемии COVID-19 и снижения цен на мировых сырьевых рынках на экономику Казахстана, Национальный банк страны проводит оперативную и слаженную работу в рамках денежнокредитной политики, в режиме инфляционного таргетирования при плавающем обменном курсе тенге. Основным инструментом денежнокредитной политики Национального банка является базовая ставка. После обвала цен на нефть и в целом на энергоресурсы НБ РК запустил ряд необходимых мер, направленных на обеспечение макроэкономической стабильности и снижение последствий внешних шоков для экономики Казахстана. Так, 10.03.2020 г. регулятор принял внеочередное решение о повышении базовой ставки до $12,0 \%$ с расширением процентного коридора до $+/-1,5$ п. п. Это решение способствовало снижению давления на курс, предотвращая рост инфляционных ожиданий и эффект переноса обменного курса на цены. С начала апреля
2020 г., учитывая риск значительного снижения экономической активности в стране, НБ РК начал процесс постепенного смягчения денежнокредитных условий, принято решение о снижении базовой ставки до 9,5\% с расширением процентного коридора до +/-2 п. п. Снижение базовой ставки в комплексе с другими антикризисными мерами позволило сгладить влияние последствий коронавируса на казахстанскую экономику и поддержать деловую активность. Далее, по мере ослабления давления на валютном рынке и снижения проинфляционных рисков, с одновременным нарастанием опасений, связанных с более резким, чем ожидалось ранее, спадом деловой активности в первом полугодии 2020 г., НБ РК в июле 2020 г. снизил базовую ставку до 9\% с сужением процентного коридора до +/- 1,5 п. П., которая сохраняется на этом уровне. Последующее снижение базовой ставки было ограничено ввиду сохранения повышенной неопределенности как на внутреннем, так и на внешних рынках. С учетом снижения базовой ставки в апреле и июле и прогноза годовой ин- 
фляции в 2020 г. значение базовой ставки в реальном выражении составило $1,9 \%$ в октябре 2020 г. Это ниже равновесного объявленного уровня в

кредитная политика носит стимулирующий характер.

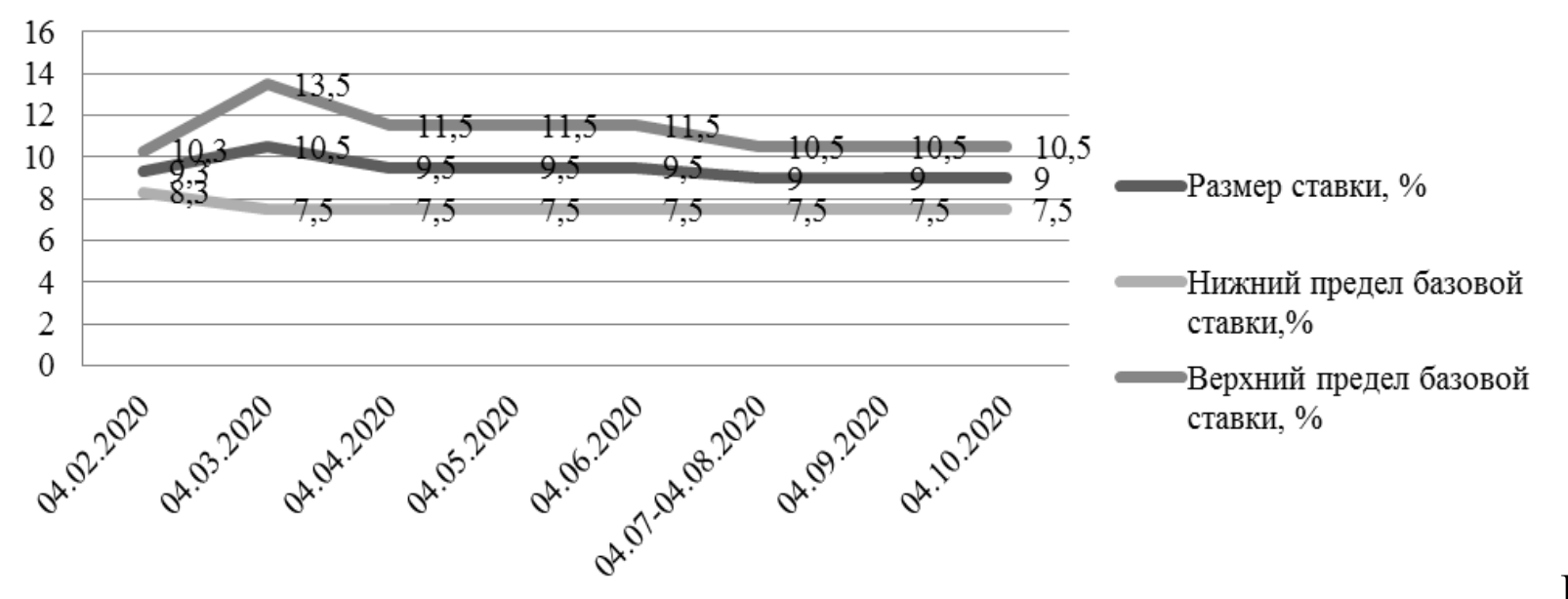

ис. 7. Размер базовой ставки в РК в 2020 г., \%

Источник: составлено автором на основе [6]

По итогам октября 2020 г. годовая инфляция составила $7,1 \%$, что несколько ниже оценок НБ РК и свидетельствует о стабилизации ситуации на потребительском рынке. В свою очередь, продовольственная и непродовольственная инфляция сложились также ниже оценок. Так, индекс цен на продовольственные товары составил $110,7 \%$ при прогнозном значении $111,5 \%$, на непродовольственные 105,6\% при прогнозе 116,7\% (рис. 8). Динамика инфляции формировалась
3\%-3,5\%. Соответственно можно сказать, что денежно-кредитная политика носит стимулирующий характер

под влиянием введения карантинных мер на фоне распространения коронавирусной инфекции и последующего повышения спроса на определенные товары [13]. Прогноз инфляции в текущем году предусмотрен в пределах 8\%-8,5\%, при этом ввиду текущей ситуации и проделанной работы НБ РК годовая инфляция по итогам 2020 г. прогнозируется ниже прогнозных значений, а в 2021 г. предполагается снижение инфляции к верхней границе целевого коридора 4\%-6\%.

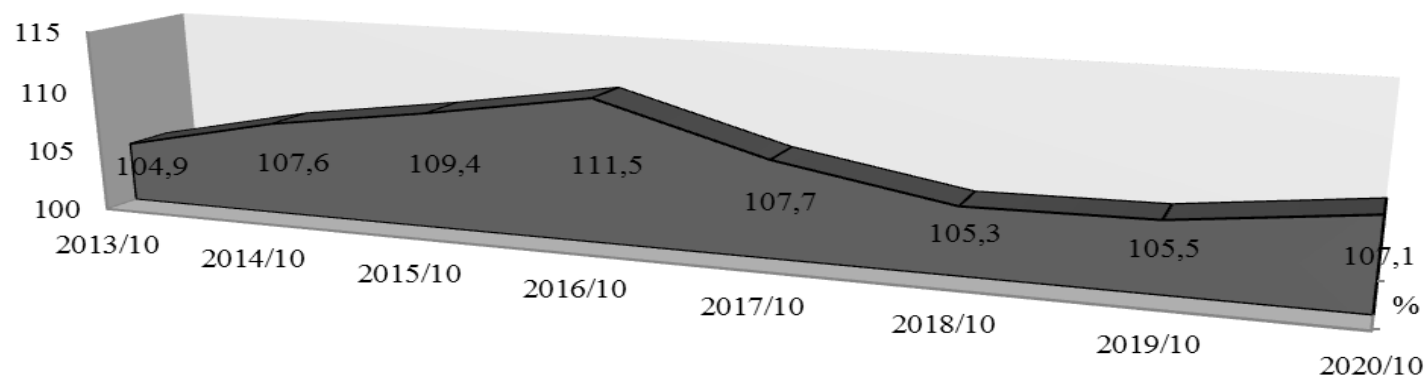

$\%$

Рис. 8. Индекс потребительских цен в РК, Источник: составлено автором на основе [13]

Решительные и своевременные дей- ствия НБ РК в рамках денежно- 
кредитной политики и проведение антикризисных мер позволили нивелировать негативные последствия кризиса и оказали положительное влияние на восстановление деловой активности в стране. Индекс деловой активности в октябре 2020 г. увеличился до $48,8 \%$, что является лучшим показателем за год. В свою очередь, кредитование экономики увеличилось на 7,1\% за год, до 14,3 трлн тг. Рост обусловлен в том числе льготным кредитованием со стороны НБ РК, который финансирует государственные и правительственные программы на общую сумму до 2,3 трлн. тг, что составляет более 50\% финансирования антикризисного пакета и является беспрецедентным. Восстановление деловой активности в стране также характеризуется положительной динамикой в ре- альном секторе экономики.

Представители МВФ дали положительную оценку антикризисным мерам НБ и Правительства РК по борьбе с пандемией коронавируса. По мнению МВФ, меры, проведённые в ответ на пандемию COVID-19 и резкое ухудшение внешних условий, были решительными и своевременными.

Казахстан поставил цель не только минимизировать последствия кризисных явлений через поддержку банков, поддержку малого и среднего бизнеса, рынка ипотечного кредитования, но и выйти на качественно новый уровень развития. Кроме того, антикризисную программу Казахстана положительно характеризуют прозрачность и поступательность.

Таблица 6

Антикризисная программа Казахстана в период кризиса

\begin{tabular}{|l|c|}
\hline \multicolumn{1}{|c|}{ Наименование мероприятия } & $\begin{array}{c}\text { Принятые } \\
\text { меры (Да/нет) }\end{array}$ \\
\hline $\begin{array}{l}\text { Повышение требований к нормативам безопасного и ликвидного функци- } \\
\text { онирования банков }\end{array}$ & Да \\
\hline $\begin{array}{l}\text { Увеличение требований к минимальному размеру уставного } \\
\text { и регулятивного (собственного) капитала }\end{array}$ & Да \\
\hline Поддержание ликвидности банков & Да \\
\hline $\begin{array}{l}\text { Совершенствование банковского законодательства и нормативных актов, } \\
\text { регулирующих деятельность банков }\end{array}$ & Да \\
\hline Совершенствование системы страхования вкладов физических лиц & Да \\
\hline $\begin{array}{l}\text { Снижение нормативов обязательных резервных требований и порядка их } \\
\text { соблюдения; ставки рефинансирования }\end{array}$ & \\
\hline
\end{tabular}

Источник: составлено автором на основе [16]

В период кризисных явлений государство заинтересовано в поддержке банков в целях обеспечения устойчивости всей финансовой системы и экономики. В связи с этим, Президентом РК поручено принять комплекс мер по оздоровлению банковского сектора. Несвоевременное принятие данных мер может снизить доверие к банкам, как экономическим посредникам, что необходимо для обеспечения стабильности экономики. Основными целями Программы являются:

- повышение эффективности надзорного процесса для предупреждения рисков в банковском секторе на раннем этапе;

- солидарная докапитализация 
банков с акционерами и обеспечение финансовой стабильности банковского сектора;

- $\quad$ восстановление кредитования реального сектора экономики;

\section{- осуществление}

бесперебойного оказания банковских услуг экономике и населению;

\section{- обеспечение}

конкурентоспособности банковского сектора в рамках интеграционных процессов (ВТО и ЕЭП).

Государственные меры по обеспечению финансовой устойчивости банковского сектора будут осуществляться по трем основным направлениям:

- изменение регулятивной и надзорной среды для повышения качества и оперативности надзорного реагирования;

- оздоровление

системообразующего банка;

- меры по докапитализации крупных банков.

Основными принципами Программы являются платность, срочность и возвратность государственных средств, добровольное участие банков и солидарная ответственность акционеров банков.

В целях обеспечения условий для оздоровления и роста капитализации банков на принципах солидарного участия акционеров, будет оказана государственная поддержка за счет инвестиций НБ РК. Акционерное общество «Казахстанский фонд устойчивости» является оператором Программы и реализует механизм финансовой поддержки банков, предоставляя денежные средства на условиях субординированного долга, соответствующего критериям для включения в состав регуляторного капитала бан- ка.

Кроме того, снижение числа игроков на банковском рынке отрицательно сказывается на уровне банковской конкуренции. Данные анализа показывают, что уровень конкуренции на банковском рынке Казахстана уступает рынкам развитых стран.

В целях финансового оздоровления банков и повышения стабильности казахстанской банковской системы необходимо последовательное проведение следующих мер: увеличение капитала банков, улучшение качества активов, реструктуризация банковской системы. Реструктуризации кредитных организаций рассматривается как одно из направлений поддержания стабильности банковской системы.

Казахстан стремится в тридцатку наиболее развитых государств. В этих странах доступность банковских кредитов обеспечивается только за счет низкой ставки рефинансирования и высокого уровня монетизации экономики. То есть, за счет адекватной денежно-кредитной политики. Никакие другие пути обеспечения доступности кредитов не используются, поскольку они приводят к искажению рыночных отношений. Текущая ситуация в Казахстане, когда государство выделяет деньги из бюджета, Национального фонда и ЕНПФ для кредитования частного и государственного бизнеса по субсидированным ставкам, является для развитых стран крайним исключением, а не нормой.

Ставки по кредитам от 6\% и выше вполне приемлемы для текущего этапа развития нашей экономики. В таких условиях бизнес и население с удовольствием берут кредиты, в результате быстро растет спрос и инвестиции в экономике, что дает большой стимул 
для роста ВВП.

Есть три ключевые причины, по которым Казахстан не смог достичь идеальной банковской системы.

Первое. Сейчас всё в экономике было бы значительно лучше, если бы правительство реализовало свои планы по диверсификации. В этом случае страна не зависела бы от цены на нефть, и экономику так не лихорадило, как сегодня. В недиверсифицированной и импортозависимой экономике, как у нас, падение цен на нефть автоматически означает девальвацию национальной валюты и последующий рост инфляции. Процентные ставки на финансовом рынке напрямую зависят от инфляции. То есть, как только увеличивается инфляция, немедленно растут ставки на депозиты и кредиты.

Второй причиной является неверная денежно-кредитная политика, которую проводил Национальный банк до февраля 2016. Если бы мы перешли на инфляционное таргетирование несколько лет назад, то даже при отсутствии диверсификации экономики текущая инфляция была бы гораздо ниже. Также у нас не было бы шоковых девальваций, подобных тем, которые случились в 2014 и 2015 гг. В отсутствие скачкообразных девальваций и инфляций доверие к тенге было бы на гораздо большем уровне, что автоматически означает низкий уровень долларизации депозитов. Поскольку сегодня, единственный драйвер для роста у нас - нефть, при низких ценах на сырье нас ждут тяжелые года. Этот сложный период может продлиться еще больше, если экономические власти продолжат совершать ошибки и не смогут завоевать доверие к себе. Пока в этом уверенности нет.

Третьей причиной является искаже- ние рыночных отношений в банковском секторе со стороны государства. Использование государственных денег для кредитования бизнеса по субсидированным процентным ставкам приводит к искажению рыночных отношений. У государства ресурсы ограничены, и оно субсидирует ставки только для очень малой части заемщиков. То есть это дает минимальный эффект для экономики, скорее, наносит большой вред. Субсидирование любого частного бизнеса приводит к снижению рыночной мотивации и развитию у реального сектора экономики бюджетного иждивенчества. Государство, вместо того, чтобы проводить разумную монетарную и фискальную политики, выступает конкурентом для коммерческих банков, искажая рыночное ценообразование в банковском секторе.

Выводы. Роль банковского сектора в развитии экономики можно повысить: минимизировав риски и обеспечив высокий уровень доверия и прозрачности, создав адекватный условиям рынка бизнес-климат. В данный момент на банковском рынке в условиях роста неопределенности обозначились опасные тенденции: валютизация, кредитование заемщиков при отсутствии признаков реальной деятельности, ненадлежащие активы банков, наличие рисков портфельных ссуд, переоцененные залоги, а также отсутствие реальных признаков связанности заемщика с собственником и другие причины. Все это снижает роль банков в создании новой стоимости, в стимулировании развития реального сектора экономики. Проведенный анализ качественных показателей деятельности коммерческих банков в Республике Казахстан, позволил сде- 
лать выводы об их позитивной динамике. Банковский сектор Казахстана по динамике своего развития намного опережает как темпы роста ВВП, так и наиболее успешные несырьевые отрасли страны. Привлекая внешнее финансирование, банки наряду с нефтяными компаниями являются основными поставщиками валютных средств в республику, оказывая существенное влияние на курсообразование национальной валюты. Рассматривая динамику капитала крупнейших банков Казахстана, представленную в ходе исследования было отмечено, что к пятерке лидеров по капиталу можно отнести Народный банк Казахстана, ДБ АО «Сбербанк», АО «KaspiBank», AO «ForteBank», AO «Банк ЦентрКредит». В целях дальнейшего развития банковского сектора, а также, учитывая предстоящее вступление Казахстана в ВТО, предполагается провести работу по совершенствованию банковского законодательства с учетом международных стандартов, развитию конкуренции либерализации доступа иностранных банков на отечественный финансовый рынок, принятию мер по совершенствованию консолидированного надзора на основе оценки рисков (с учетом действующих конгломератов в РК и возникающих в связи с этим рисков), снижению банковских рисков связанных с экспансией банков на внешние рынки, потребительским кредитованием и кредитованием малого бизнеса, совершенствованию финансовой статистики.

\section{Список литературы}

1. Сейткасимов, Г.С. Банковское дело: учебник. А.: Каржы-каражат, 2011. 182 с.

2. Жоламанова, М.Т. Деньги. Кредит. Банки: Учебное пособие. Алматы: Евразийский институт рынка, 2011. 384 с.

3. Мақыш С.Б. Банк ісі: Оқулық. Алматы: Жеті жарғы, 2009. 552 бет.

4. Официальный сайт Агентства Республики Казахстан по регулированию и развитию финансового рынка. URL: https://www.gov.kz.

5. О Национальном Банке Республики Казахстан: Закон РК от 30 марта 1995 года № 2155. URL: https://online.zakon.kz/Document/?doc_id=1003548. (дата обращения: 10.04.2021)

6. Официальный интернет-ресурс Национального банка Республики Казахстан. URL: https://www.nationalbank.kz. (дата обращения: 10.04.2021)

7. О банках и банковской деятельности в Республике Казахстан: Закон РК от 31 августа года № 19952444.2 URL: https://online.zakon.kz/document/?doc_id=1003931. (дата обращения: 10.04.2021)

8. Банковское дело: учебное пособие / Л. И. Юзвович та ін.; под ред. Н. Н. Мокеевой. Екатеринбург: Изд-во Урал. ун-та, 2020. 296 с.

9. Соколинская Н.Э. Банки, монетарное регулирование и финансовые рынки 
на пути к устойчивому росту экономики: монография. М.: Русайнс, 2018. 119 с. 10. Коробова Г.Г. Банковское дело: учебник. М.: Магистр, 2018. 480 с.

11. Текущее состояние банковского сектора Республики Казахстан по состоянию на 1 марта 2020 года. URL: https://www.gov.kz. (дата обращения: 10.04.2021)

12. Текущее состояние банковского сектора Республики Казахстан по состоянию на 1 марта 2021 года. URL: https://www.gov.kz. (дата обращения: 10.04.2021)

13. Бюро национальной статистики Агентства по стратегическому планированию и реформам Республики Казахстан. URL: https://www.gov.kz/memleket/entities/stat?lang=ru. (дата обращения: 10.04.2021) 14. Niyazbekova Sh., Kosmagambetova, S. Global banking crises: causes, factors and implications. Вестник финансового университета. 2014. 1. С. 110-121.

15. Caprio, G., Klingebiel, D. (1997). Bank In solvency: Bad Luck, Bad Policy, or Bad Banking? Annual World Bank Conference on Development Economics 1996. Washington, DC, p. 79-104.

16. Об итогах работы банковских систем государств-участников ЕврАзЭС и перспективах развития банковского сектора государств Сообщества. URL: http://www.evrazes.com. (дата обращения: 10.04.2021) 